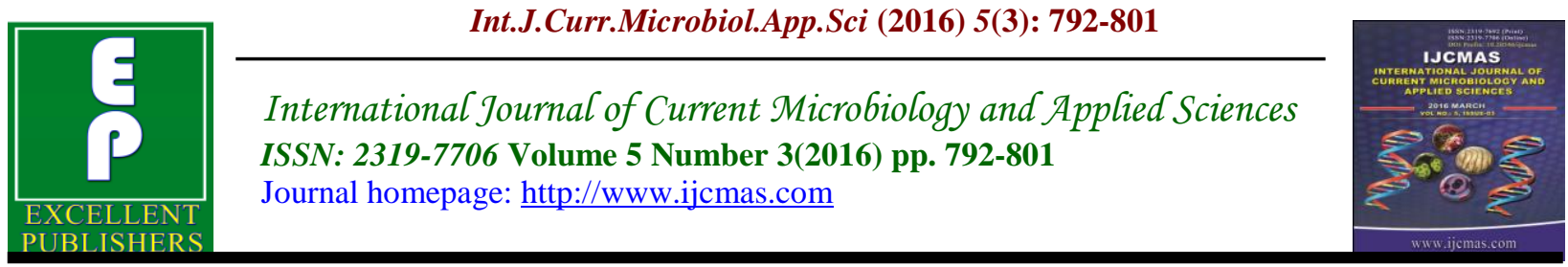

Original Research Article

http://dx.doi.org/10.20546/ijcmas.2016.503.092

\title{
Survey of Coleopteran Insects on Alfalfa Plant
}

\author{
Razzaq Shalan Augul* and H. H. Al-Saffar \\ Iraq Natural History Research Center and Museum- University of Baghdad, Iraq \\ *Corresponding author
}

\begin{abstract}
A B S T R A C T
Keywords

Alfalfa, Beetles, Coleopteran, Iraq, Medicago sativa, Pests

Article Info

Accepted:

22 February 2016

Available Online:

10 March 2016

In this study, 81 specimens of the beetles associated with alfalfa fields, were collected from different region of Iraq are investigated. 17 species belonging to 16 genera and 8 families were determined; these species are: Sitona sp., Hypera postica (Gyllenhal), Lixus scolopax (Boheman), Spermophagus sericeus (Geoffroy), Clanoptilus judex (Abeille de Perrin), Clanoptilus viridanus (Mulsant \& Wachanru), Clytra valeriana Menetries, Altica deserticola (Weise), Aulacophora foveicollis (Lucas), Coccinella septempunctata (Linnaeus), Hippodamia variegata (Goeze), Stethorus gilvifrons (Mulsant), Scymnus interruptus (Goeze), Adalia bipunctata (Linnaeus), Omophlus sp., Tropinota squalida (Scopoli) and Certallum ebulinum (Linnaeus).The specimens of Curculionidae were collected in high percent, whereas Cerambycidae was lowest percent.
\end{abstract}

\section{Introduction}

Alfalfa has been cultivated for forage longer than any other crop. Not only does alfalfa have very high yield potential, but it is also one of the most palatable and nutritious forage crops, because of its high protein and vitamin content; alfalfa is a primary component in the diet of dairy cattle as well as beef cattle and horses Alfalfa, Medicago sativa Linnaeus, is among the most prized of forage and is grown worldwide (Summers, 1998).

Alfalfa plant provides a large number of arthropods; some of them are pests, but many have no effect on the crop (Alsuhaibani, 1996). Alfalfa supports a diverse arthropod fauna; at least 1,000 species have reported from alfalfa in the United States, with perhaps $100-150$ of these causing some degree of injury. Few of these, however, can be described as key pest species, the rest are of only local or sporadic importance, or are incidental herbivores, entomophagous (parasites and predators), or pollinators (Flanders and Radcliffe, 2013).

Beetles tend to visit flowers to feed generally on floral tissue, and may damage the flowers and developing fruit in the process. Some groups of beetles, such as the flower scarabs and members of families Melyridae and Mordellidae are adapted to use floral resources. Some soldier beetles 
(family Cantharidae) feed extensively on pollen and can move to many different flowers during their adult lives.

In Iraq, there were several studies on alfalfa insects, such as: Ghaeb (1978), Augal et al. (2012) and Al -Saffar (2013).

The aim of this study was to determine the prevalence of the coleopteran species which were founded on alfalfa in different regions from middle and south of Iraq.

\section{Materials and Methods}

Many samples were collected from alfalfa in several region of Iraq, by using sweeping net during 2015. The coleopteran insects were killed by freezing for 24 hours, some coleopteran were mounted by insect pin , small kept in gelatin capsules; the date and localities of sampling were recorded.

Coleopteran were diagnosed by using different taxonomic keys such as: Duffy (1952), Pope (1953), Crowson (1956), Brendell (1975), Ismail (1983), Jessop (1986), Khudair (2014), Gruve and Dober (2005) and Saleh (2007); In addition to comparing it with samples diagnosed earlier and stored at the Iraq Natural History Research Center and Museum, University of Baghdad. Dino light microscope was used for taking photo of samples with scale of measurements.

\section{Results and Discussion}

In this investigation there are 17 species (Plate 1, 2 and 3) belong to 16 genera and 8 families were collected; In total the percent of alfalfa beetle groups investigated were recorded; Curculionidae most abundant with $29.63 \%$ of the total number of individuals, followed by Malachiidae $17.28 \%$, Chrysomelidae $14.81 \%$, Bruchidae $13.58 \%$, Coccinellidae $11.11 \%$, Scarabaeidae $8.64 \%$,
Tenebrionidae 3.7 and Cerambycidae 1.23 $\%$.

A list of the species is given below:

\section{Curculionidae}

\section{Sitona sp.}

Sitona species specialize on legumes, plants of the family Fabaceae, the larvae eat root nodules and the adults eat leaves (Velázquez de Castro et al., 2007). Arbab and McNeill (2014) mentioned that several species of Sitona weevils are important agricultural pests of alfalfa.

Materials Examined (4 specimens): Wasit prov. Al Zubaidya-Sherhan vill, 4, 28. May. 2015.

Distribution: Holarctic region (Velázquez de Castro et al., 2007).

\section{Hypera postica (Gyllenhal, 1813)}

This species is the most damaging phytophagous pest and the major limiting factor in alfalfa production in the most regions of the world (Blodgett et al., 2000). Direct alfalfa weevil damage is caused by adults and larvae feeding on the growing tips, leaves and buds of alfalfa, which removes crop biomass and reduces harvested yield (Fick \& Liu, 1976). Shebl et al. (2009) were found the alfalfa weevil Hypera postica is the most important insect pests of alfalfa in his investigations.

Materials Examined (17 specimens): Baghdad province: Al-Mada'in, 4, 18.Apr.2015; Bab Al Muadham, 1, 22. May. 2015. Wasit prov., Ash Shahabi, 12, 18. Jun. 2015.

Distribution: Iraq( Derwesh, 1965); East Palaearctic, Near East (Asian Turkey, 
Caucasian Russian republics, Georgia, Armenia, Azerbaijan, Lebanon, Syria, Israel, Jordan, Egypt, Arabian peninsula, Iran, Nearctic region, North Africa (Anonymous, 2009).

Lixus scolopax (Boheman, 1836)

Dieckmann (1983) referred that the Asteraceae is the host plants of this species; whileAlsuhaibani (1996) was registered Lixus sp. as phytophagous insects on alfalfa plant, and agreement with the present study, and we expected the alfalfa plants also another host plant for this species.

Materials Examined (3 specimens): Baghdad province: Jaddria, 3, 3.Nov.2015.

Distribution: Iraq (Derwesh, 1963) Western Palaearctic (Dieckmann, 1983).

\section{Family: Bruchidae}

Spermophagus sericeus (Geoffroy, 1785)

There are approximately 90 species of Spermophagus that have been described in the Old World. Twenty-four species of Spermophagus have been reported to feed in species of Convolvulaceae (Romero and Johnson, 2000). In Europe, Spermophagus sericeus only known species to breed on seeds of Convolvulus arvensis L. (Southgate, 1979).Based on the above, the presence of this species on alfalfa plant in our investigations, it plays the role of important pollinators of flowers.

Materials Examined (11 specimens): Baghdad province: Bab Al- Muadham, 3, 24.Apr.2015; Wasit prov. Ash Shahabi, 8, 18. Jun. 2015.

Distribution: widely distributed in the Palearctic region (Borowiec, 1985),
Derwesh (1965) was listed this species in Iraq.

Family: Malachiidae

Clanoptilus judex (Abeille de Perrin, 1885)

Ezzatpanah (2011) mentioned that species of Clanoptilus makhani Ezzatpanah, 2011 was feeding on pollen from flowers of Poaceae; but in our investigations we collected the specimens of the Clanoptilus judex on flowers of alfalfa.

Material Examined (9 specimens): Baghdad province: Bab Al- Muadham, 2, 2.May.2015; Al-Mada'in, 4, 18.Apr.2015. Wasit province: Al-Zubaidya, 2, 24.Apr.2015; Aziziyah, 1, 2.May.2015.

Distribution: Palearctic region (Löbl \& Smetana, 2007).

Clanoptilus viridanus (Mulsant \& Wachanru, 1852)

Synonym in Iraq: Malachius viridanusMulsant \&Wachanru, 1852.

This species also in previous, it was collected from flowers.

Material Examined (5 specimens): Wasit: Al Dabuny, 5, 5.May.2015.

Distribution: Iraq (Derwesh, 1965); Lebanon, Syria, Turkey (Yildirim and Bulak, 2012).

\section{Family: Chrysomelidae}

Clytra valeriana Menetries, 1832

Adults of this family are living on a life plants, usually consuming the leaves and flowers (Chapman, 1982), in our 
investigations the specimens of this species are shown feeding on flowers of alfalfa.

Material Examined (2 specimens): Baghdad province: Al-Mada'in, 2, 18.Apr.2015.

Distribution: Iraq (Derwesh,1965); South Russia, Iran, Turkey, Greece (Clavareau, 1913); S European Russia, E Mediterranean (Winkler, 1924-1932); S Ukraine, Rostov Region, Stavropol Region, Caucasus, Transcaucasia, Balkan Peninsula (Lopatin, 1984); Greece and Bulgaria, Central Asia, Caucasus (Warchalowski, 2003).

Altica deserticola (Weise, 1889)

Altica deserticola is phytophagous;Furth (1980) referred to the host of this species is Unknown; whereas Aslan et al. (2004) collected this species from Epilobium (Onagraceae)and Glycyrrhiza glabra Linnaeus (Fabaceae), and the species collected from Medicago sativa in the current study and we expect to have this species of beetles more than a host plant.

Material Examined (7 specimens): Iraq, Baghdad province: Jaddria, 7, 3.Nov.2015.

Distribution: Iraq (Derwesh, 1965); SE Russia, Caucasus, Armenia, Turkestan, Siberia; Mongolia; China and Taiwan (Kimoto, 1971); Turkey, Iran, Afghanistan (Lopatin, 1963); Syria, Jordan and Israel.

\section{Aulacophora foveicollis (Lucas, 1849)}

This species as pest on many plants, the adults are feed on leaves and flowers; the current results agreement with Rashid \& khan (2014), they were mentioned that the species of $A$. foveicollis is polyphagous feed voraciously on leaves, flower buds and flowers which may reach up to $35-75 \%$ at seedling stage.

Material Examined (3 specimens): Erbil province: Shaqlawa, 3, 10.10.2015.

Distribution: France, Greece, Italy, Portugal, Spain. Egypt, Afghanistan, Cyprus, Oman, Pakistan, Saudi Arabia, Russia, Syria, Turkey, Yemen, Afrotropical region and Oriental region (Ahmad et al., 2013).

\section{Family: Coccinellidae}

In previous studies, Abdulmadzhid (1973) recorded 11 species of Coccinellidae in fields of alfalfa. The natural enemies or predators of aphids that parasites on Medicago sp. were studied by many authors such as: Wheeler (1977), Takahashi and Naito (1984) and Shebl et al. (2009). The occurrence of coccinellid species are most beneficial in fields of alfalfa, because their natural enemies for aphids.

Coccinella septempunctata (Linnaeus, 1758)

Material Examined (4 specimens): Baghdad province: Al-Mada'in, 4, 18.Apr.2015.

Distribution: Cosmopolitan (Ashfaque et al., 2013).

Hippodamia variegata (Goeze, 1777)

Material Examined (1 specimen): Baghdad province: Jaddria, 1, 15.Apr.2015.

Distribution: Iraq (Derwesh, 1965); wide distribution range in the Palearctic and extends to Nearctic areas (Obrycki and Orr, 1990).

Stethorus gilvifrons (Mulsant, 1850) 
Plate.1 A- Sitona sp. B- Hypera postica C- Lixus scolopax D- Spermophagus sericeus E- Clanoptilus judex F- Clanoptilus viridanus G- Clytra valeriana H- Altica deserticola

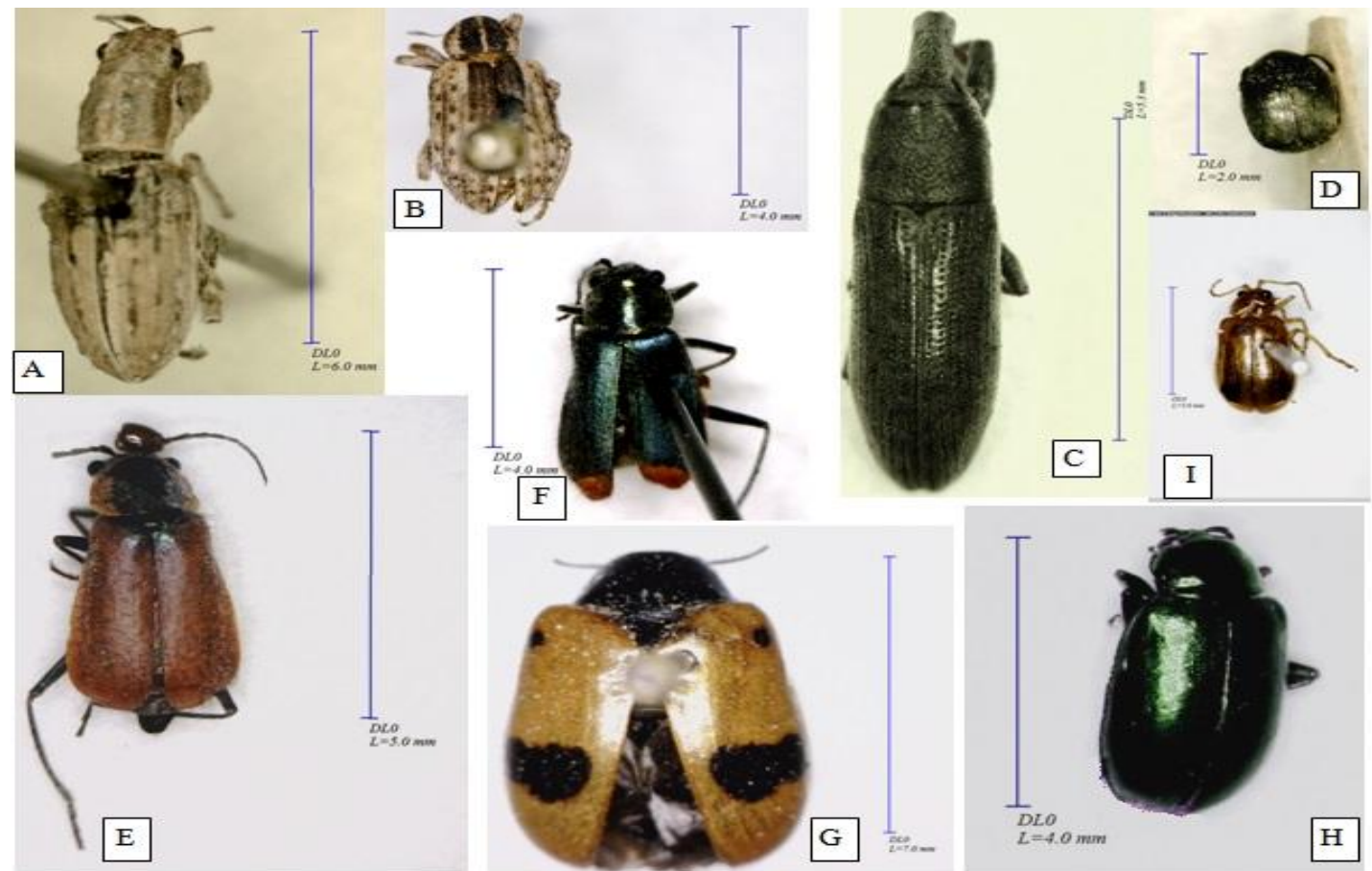

Plate.2 A- Coccinella septempunctata B- Hippodamia variegata C- Stethorus gilvifrons DScymnus interruptus E- Adalia bipunctata

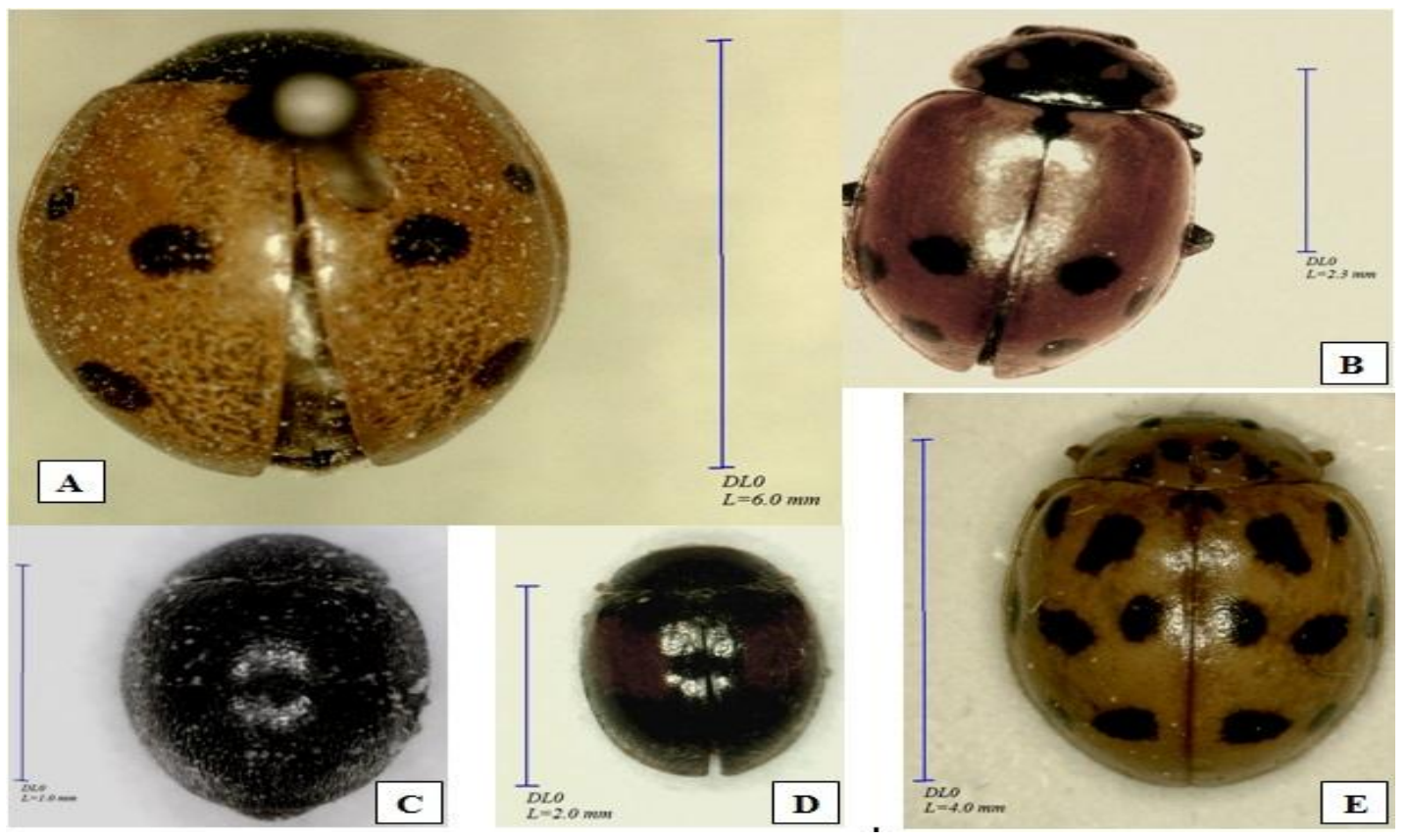


Plate.3 A- Omophlus sp. B- Tropinota squalida C- Certallum ebulinum

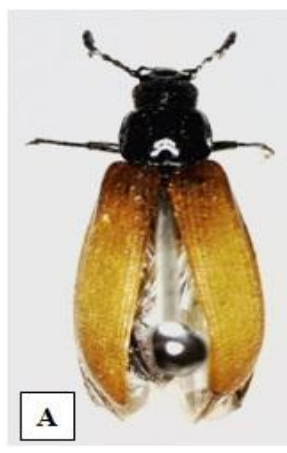

Material Examined (1 specimen): Baghdad province: Jaddria, 1, 3.May.2015.

Distribution: Mediterranean Region, Middle East, Saudi Arabia, Pakistan, Kashmir, India and Oriental Region (Samin and Shojai, 2013).

Scymnus interruptus (Goeze, 1777)

Material Examined (2 specimens): Baghdad province: Jaddria, 2, 3.Nov.2015.

Distribution: Iraq (Derwesh, 1963); Palaearctic species (Serafim, 1997).

Adalia bipunctata (Linnaeus, 1758)

Synonym: Adalia fasciatopunctata (Faldermann, 1835) according to Hodek et al.(2012).

Material Examined (1 specimen): Erbil province: Shaqlawa, 1, 6.July.2015.

Distribution: Central Asia, Europe and North America (Hodek, 1973; Hodek \& Honěk, 1997).

\section{Family: Tenebrionidae}

Omophlus sp.

Most species are of unknown economic importance, although larvae of Omophlus and related genera are root feeders, and have been recorded as pests of potatoes and sugar beet (Booth et al., 1990). Adults of this species were collected on flowers, because they feeding on pollen.

Material Examined (3 specimens): Erbil province: Shaqlawa, 1, 17.May.2015

Distribution: Widely distributed in Palaearctic region (Yildirim and Kiliç, 2008); Iraq (Derwesh, 1965).

\section{Family: Scarabaeidae}

Tropinota squalida (Scopoli, 1783)

Our results agree with Shebl et al. (2009); they list this species in most pest insects in alfalfa field in Egypt.

Material Examined (7 specimens): Erbil province: Shaqlawa, 7, 25.April.2015.

Distribution: Europe (Albania, Boznia Herzegovina, Bulgaria, Croatia, France, Greece, Italy, Malta, Macedonia, Portugal, Slovenia, Spain, Switzerland, Serbia, Montenegro and Turkey); Asia and North Africa (Pivotti et al., 2011); Iraq (Derwesh, 1965).

Family: Cerambycidae 
Certallum ebulinum (Linnaeus, 1767)

Ambrus et al. (2014) collected this species on flowers belong to different species of plants; in our investigations the members of this species also were collected from flowers of alfalfa. That means these beetles are important and flower pollinators.

Material Examined (1 specimen): Erbil province: Shaqlawa, 1, 25.April.2015.

Distribution: Iraq (Derwesh, 1963) Europe (Portugal, Spain, France, Malta, Greece, Bulgaria, European Turkey, Ukraine, European Russia), Caucasus, Turkey, Iran, Iraq, Israel, Jordan, Lebanon, Syria, Cyprus, North Africa: Algeria, Egypt, Libya, Morocco and Tunisia) (Okutaner et al., 2011).

\section{References}

Abdulmadzhid, A.A. 1973. Control of Acyrthosiphon pisum with natural enemies and insecticides. RastitelnaZashchita, 21(7): 39-41.

Ahmad, W., Naeem, M., Bodlah, I. 2013. Genus Aulacophora Chevrolat, 1836(Coleoptera: Chrysomelidae) from Pothohar, Punjab, Pakistan. Pakistan. J. Zool., 45(3): 868-871.

Al Saffar, H.H. 2013. Survey of Brachycera flies on alfalfa. Bull. Iraq nat. Hist. Mus., 12(4): 1-5.

Alsuhaibani, A.M. 1996. Entomofauna of Alfalfa in Riyadh, Saudi Arabia, $J$. King Saud Univ. Agric. Sci., 8(2): 269-277.

Ambrus, R., Grosser, W., Hrbek, J. 2014. Contribution to the knowledge of longhorn beetles from Cyprus (Coleoptera: Cerambycidae). Humanity Space Int. Almanac, 3(2): 173-190.

Anonymous, 2009. Fauna Europaea. (Web page: http://www.faunaeur.org /distribution_table.php.

Arbab, A., McNeill, M.R. 2014. Spatial distribution and sequential sampling plans for adult Sitona humeralis Stephens (Coleoptera: Curculionidae) in alfalfa. J. AsiaPacific Entomol., 17: 515-519.

Ashfaque, M., Ullah, F., Rafi M.A. 2013. Genus Coccinella (Coccinellidae: Coleoptera) from Gilgit-Baltistan with two new records from Pakistan. Sarhad J. Agric., 29(2): 239-247.

Aslan, I., Calmasur, O., Bilgin, O.C. 2004: A morphometric study of Altica oleracea(Linnaeus, 1758) and $A$. deserticola(Weise, 1889) (Coleoptera:Chrysomelidae: Alticinae). Entomol. Fennica, 15: 15.

Augul, R.S., Mzhr, N.N., Abul-Rassoul, M.S. 2012. Occurrence of hemipteran species on alfalfa plant in Baghdad. Bull. Iraq nat. Hist. Mus., 12(2): 7-13.

Blodgett, S.L., Lensson, A.W., Cash, S.D. 2000. Harvest with raking for control of alfalfa weevil (Coleoptera: Curculionidae). J. Entomol. Sci., 35: 129-135.

Booth, R.G., Cox, M.L., Madge, R.B. 1990. The guides to insects of importance to man. 3. Coleoptera. International Institute of Entomology, the Natural History Museum, Wallingford, UK, $384 \mathrm{pp}$.

Borowiec, L. 1985. Notes on the Palearctic Spermophagus Schoenherr (Coleoptera, Bruchidae, Amblycerinae), with description of two new species. Polskie Pismo Entomologiczne, 55: 3-24.

Brendell, M.J.D. 1975. Coleoptera: Tenebrionidae. Handbook for identification of British Insects. Royal Entomological Society of 
London. Vol. 5, Part 10, 27pp.

Chapman, R.F. 1982.The Insects: Structure and Function. $3^{\text {rd }}$ edition. Cambridge, mass, Harvard university press, $919 \mathrm{pp}$.

Clavareau H. 1913. Pars 53. Chrysomelidae: 5. Megascelinae, 6. Megalopodinae, 7. Clytrinae, 8. Cryptocephalinae, 9. Chlamydinae, 10. Lamprosominae. IN: S. Schenkling (ed.), ColeopterorumCatalogus. W. Junk, Berlin, 278 pp.

Crowson, R.A. 1956. Coleoptera: Introduction and key to families. Handbook for Identification of British Insects. Royal Entomol. Soc. London. Vol. 4, Part 1, 59 pp.

Derwesh, A.I. 1963. A preliminary list of Coleoptera from Iraq. Director General Agriculture Research Projections Baghdad. Technical Bulletin, No. 13, 38 pp.

Derwesh, A.I. 1965. A preliminary list of identified insects and arachnids of Iraq. Director General Agriculture Research Projections Baghdad. Bulletin, 112: 121-123.

Dieckmann,

L.

1983

BeiträgezurInsektenfauna der DDR: Coleoptera - Curculionidae (Tanymecinae, Leptopiinae, Cleoninae, Tanyrhynchinae, Cossoninae, Raymondionyminae, Bagoinae, Tanysphyrinae). Mit 164 Textfiguren.

Beiträgezur Entomologie, 33(2): 257-381.

Duffy, E.A.J. 1952. Coleoptera: Cerambycidae. Handbook for identification of British Insects. Royal Entomol. Soc. London. Vol. 5, Part 12, 18 pp.

Ezzatpanah, S. 20011.Clanoptilus makhani sp. nov., a new species of softwinged flower beetle from Gerdoo Mountain, Arak, Markazi Province, Iran (Coleoptera: Malachiidae).
Calodema, 169: 1-4.

Fick, G.W., Liu, B.W.Y. 1976. Alfalfa Weevil Effects on Root Reserves, Development Rate, and Canopy Structure of Alfalfa. Agronomy J., 2: 595-599.

Flanders, K.L., Radcliffe, E.B. 2013. Alfalfa IPM. In: E. B. Radcliffe, W. D. Hutchison, and R. E. Cancelado (eds.), Radcliffe's IPM World Textbook, University of Minnesota, St. Paul, MN. (http://ipmworld.umn.edu) (Accessed February, 2016).

Furth, D.G. 1980. Altica of Israel (Coleoptera: Chrysomelidae: Alticinae). Israel J. Entomol., 14: 55-66.

Ghaeb, W.A. 1978. Arthropods associated with alfalfa: their population densities and interrelationships in Abu - Ghraib, Iraq. M. sc. Thesis, Agricultural Collage, Baghdad University, 108 pp. (in Arabic)

Hodek, I. 1973. Biology of the Coccinellidae. Academia. Prague, $260 \mathrm{pp}$.

Hodek, I., Honek, A. 1996. Ecology of Coccinellidae. Kluwer Academic Publisher, Dordrecht, 464 pp.

Hodek, I., Van Emden, H.F, Honek, A. 2012. Ecology and Behavior of the Ladybird Beetles (Coccinellidae). Blackwell Publishing Ltd.

Ismail, S.I. 1983. Taxonomic study to the family of long horn borer (Coleoptera: Cerambycidae) in Iraq. M.sc. thesis, Collage Science, Baghdad University, 199pp. (in Arabic)

Jessop, L. 1986. Dung Beetles and Chafers (Coleoptera: Scarabaeoidea). Handbook for Identification of British Insects. Royal Entomol. Soc. London. Vol. 5, Part 11, 57 pp.

Khudair, R. O. 2014. Taxonomic study on 
the flea beetles (Coleoptera: Chrysomelidae: Alticinae) in some region of Iraq. Msc. thesis of Entomology, Zoology - Basic Education, University of $\mathrm{Al}-$ Mustansiryia., 144 pp. (in Arabic)

Kimoto, S. 1971. Notes on the Chrysomelidae from Taiwan VI. Entomological Rev. Japan, 23(2): 73-87.

Löbl, I., Smetana, A. (eds.). 2007. Catalogue of Palaearctic Coleoptera: Elateroidea, Derodontoidea, Bostrichoidea, Lymexyloidea, Cleroidea and Cucujoidea. Vol. 4, $1^{\text {st }}$ Edition, Apollo Books, 935 pp.

Lopatin, I. 1963. Die Chrysomeliden (Coleoptera) Afghanistans auf Grund der Ergebnisse der For schungsreise des Herrn. 3. Klapperich in den Jahren 1952/53. Annales HistoricoNalurales Muse/Nationally Hungarici. Pars Zoologica, 55: 349 378.

Lopatin, I.K. 1984. Leaf-beetles (Chrysomelidae) of Middle Asia and Kazakhstan, Oxanion press, New Delhi, 413 pp.

Obrycki, J.J., Orr, C.J. 1990. Suitability of three prey species for Nearctic populations of Coccinella septempunctata, Hippodamia variegata and Propyleaquatro decimpunctata (Coleoptera: Coccinellidae). J. Economic Entomol., 83: 1292-1297.

Okutaner, A.Y., Özdikmen, H., Yüksel, E. and Koçak, Y. 2011. A synosis of Turkish Certallini Fairmaire, 1864 with a cytogenetic observation (Coleoptera: Cerambycidae: Cerambycinae). Munis Entomol. Zoology, 6(2): 937-943.

Pivotti, I., Agoglitta, R., Zunino, M., Piattella, E., Dellacasa, M., Corallini, C., Mifsud, D. 2011.The
Scarabaeoidea of the Maltese Islands (Central Mediterranean) (Coleoptera). Bulletin of the Entomol. Soc. Malta, 4: 85-124.

Pope, R.D. 1953. Coleoptera: Coccenillidae and Sphindidae. Handbook for identification of British Insects. Royal Entomol. Soc. London, Vol. 5, Part 7, 17 pp.

Rashid, M.A., Khan, M.A. 2014. Red Pumpkin Beetle, Aulacophora foveicollis Lucas. A Review of Host Susceptibility and Management Practices. Academic J. Entomol., 7(1): 38-54.

Romero, J., Johnson, C.D. 2000. Revision of the genus Zabrotes Horn of Mexico (Coleoptera: Bruchidae: Amblycerinae). Trans. Act. Am. Entomol. Soc., 126: 221-74.

Saleh, A.M. 2007. Taxonomic study of some species, the two subfamilies: Brachyderinae and Cleoninae (Coleoptera: Curculionidae) in some region of Iraq. Msc. thesis of Entomology, Zoology - Basic Education, University of $\mathrm{Al}-$ Mustansiryia , 144 pp. (in Arabic)

Samin, N., Shojai, M. 2013. A study on Coccinellidae (Coleoptera: Cucujoidea) from Varamin. Linzer biol. Beitr., 45(2): 2121-2126.

Serafim, R. 1997. Contributions to the knowledge of the distribution of Coccinellidae and Cerambycidae (Coleoptera) in Maramureş depression and Rodnei Mountains (Romania). Tnv. Mur. Natl. Hist. Nat. "Grigore Antipa", 37: 69-87.

Shebl, M.A., Kamel, S.M., Abu Hashesh, T.A., Osman, M.A. 2009. The Most Common Insect Species in Alfalfa Field in Egypt. Phegea, 37(3): 97102.

Southgate, B.J. 1979. Biology of the Bruchidae. Annu. Rev. Entomol., 24: 
449-73.

Summers, C.G. 1998. Integrated pest management in forage alfalfa. Integrated Pest Management Reviews, 3: 127-154.

Takahashi, K., Naito, A. 1984. Seasonal occurrence of aphids and their predators (Col.: Coccinellidae) in alfalfa fields. Bulletin of the National Grassland Research Institute, Japan, 29: 62-66.

Velázquez de Castro, A.J., AlonsoZarazaga, M.A., Outerelo, R. 2007. Systematics of Sitonini (Coleoptera: Curculionidae: Entiminae), with a hypothesis on the evolution of feeding habits. Systematic Entomol., 32: 312-331.

Warchalowski, A. 2003. Chrysomelidae, The Leaf Beetles of Europe and the
Mediterranean area. Natura optima dux Foundation, Warszawa, 600 pp.

Wheeler, A.G. 1977. Studies on the arthropod fauna of alfalfa: VII. Predaceous insects. Canadian Entomologist, 109(3): 423-427.

Winkler, A. 1924-1932. Catalogus Coleopterorum regionis Palearcticae. Albert Winkler XVIII, Dittesgrasse II, Vienna, 1698 pp.

Yildirim, E., Bulak, Y. 2012. Contribution to the knowledge of the Malachiidae (Coleoptera: Cleroidea) fauna of Turkey. Türk. entomol. derg., 36(2): 231-238.

Yildirim, E., Kiliç, E. 2008. Distributional checklist of the species of genus Omophlus (Insecta: Coleoptera; Alleculidae; Omophlinae) of Turkey. Linzer biol. Beitr., 40(1): 961-967.

\section{How to cite this article:}

Razzaq Shalan Augul and Al-Saffar, H. H. 2016. Survey of Coleopteran Insects on Alfalfa Plant. Int.J.Curr.Microbiol.App.Sci. 5(3): 792-801. doi: http://dx.doi.org/10.20546/ijcmas.2016.503.092 